\title{
SOME METHODOLOGICAL ASPECTS OF THE EVALUATION OF STUDENTS' EDUCATIONAL ACHIEVEMENTS AT UNIVERSITY
}

\author{
Dr. Olga V. Galustyan, Southern Federal University, Department of Foreign Languages, Rostov-on-Don, Russia \\ E-mail: ovgalustyan@sfedu.ru
}

ARTICLE INFO

Studies and articles

Received: May, 04.2017.

Revised: May, 30.2017.

Accepted: Jun, 05.2017.

doi:10.5937/IJCRSEE1701043G

UDK

$371.26-057.874$

159.947.5-057.874

\section{Keywords:}

Evaluation,

Activity Approach,

Contextual Approach,

Students,

University

\section{A B S T R A C T}

The article deals with some methodological aspects of evaluation of students' educational achievements at university. Evaluation being as an essential component of the educational process includes controlling, measurement and assessment. Studying the methodological aspects of evaluation, we refer to the activity and contextual approaches. Activity approach involves using of the active forms and methods of evaluation, such as web-quests, discussions, presentations of the projects, portfolio, etc. Contextual approach allows to organize the evaluation of students' educational achievements, providing the professional activities, which help them to master their skills. The author concludes that the use of contemporary forms of evaluation in the educational process of the university will contribute to the effectiveness of the educational process itself.

() 2017 IJCRSEE. All rights reserved.

\section{INTRODUCTION}

Higher education is undergoing global changes in the modern world. Nowadays modern society demands a new type of a competent professional in the field of the professional activities. Today, modern higher education is not just a set of knowledge, but also a formation of a coherent picture of the world with its norms, ideals, values, which serve as a reference point of the human relations. It is a fact, that there are more requirements to the modern university graduates (Stošić, L., 2015; Stošić, L. and Stošić, I., 2013; Galustyan, O. V., 2014, 2015). It is necessary to educate the specialists of a new type, the main characteristics of whose is high-level professional qualification, ability to self-development, critical thinking, ability to solve professional problems of different levels. The competitiveness of contemporary specialists relates to the level of the development of their competences. Thus, the problem of students' evaluation of educational achieve-

Corresponding Author

Dr. Olga V. Galustyan, Southern Federal University, Department of Foreign Languages, Rostov-on-Don, Russia, E-mail: ovgalustyan@sfedu.ru

This work is licensed under a Creative Commons Attribution - NonCommercial - NoDerivs 4.0. The article is published with Open Access at www.ijcrsee.com ments at university is urgent nowadays.

The main theoretical aspects of students' evaluation of educational achievements were studied by (Balzer, L., 2006, 2015; Balzer, L. et al., 2002; Gowin, D. B. and Millman, J. 1981; Kromrey, H., 2003; Wottawa, H. and Thierau, H., 2001). The categories reflected in their works allowed to identify the general idea that the evaluation of students' educational achievements is the essential component of the educational process which includes controlling, measurement and assessment. Controlling includes checking and measurement, and, thus, eliminates the management of the educational process; measurement includes estimation and assessment; assessment represents only testing.

The analysis of the psychological and pedagogical literature devoted to the evaluation in the educational process has shown, that the scientists, who work on problems of higher education, confirm the need of the systematic study of the issues related to the organization of evaluation of students' educational achievements at contemporary high school. The authors (Balzer, L., 2006, 2015; Balzer, L. et al., 2002; Gowin, D. B. and Millman, J. 1981; Kromrey, H., 2003; Wottawa, H. and Thierau, H., 2001) note that the evaluation as the major component of the teaching and learning process of contemporary higher education requires the constant updating of diag- 
nostic tools and the development of the evaluation criteria of learning outcomes.

\section{ACTIVITY AND CONTEXTUAL APPROACHES}

The important methodological guideline of organizing evaluation of students' educational achievements is activity approach. The main ideas of activity approach are discussed in the works of Russian scientists (Asmolov, A. G. 2009; Davydov, V. V., 1972, 1981; Davydov, V. V. at all., 1982; El'konin, D. B. at all., 1989; Galperin, P. Y., 1999; Galperin, P. Y. and Talyzina, N. F., 1979; Lektorsky, V. A. 2008; Levina, M. M., 2009; Rubinstein, S. L., 1989; Schedrovitsky, G. P. and Kotelnikov, S. I., 1983; Slobodchikov, V. I., 1998). The leading idea of the activity approach is providing personal and professional development which is based on the active position of the student. The basic category of this approach is the category of activity. When Rubinstein S. L. (1989) was making the analysis of the basic psychological processes of human activity, he concludes, that activity is a human relation to the world, in case it is purposeful and conscious. Leontiev A. N. (1976) confirms the relation of the consciousness to activity as well. The scientist considers the equivalent of activity is the action itself. The research by Leontiev A. N. (1976) suggests that the activity is also a condition for the formation of human sense. That means, that the activities generate a sense of evaluation of students' educational achievements, thus, the development of reflection is going on. Lektorsky V. A. (2008) declared that there was special importance of reflection in students' activities. Lektorsky V. A. (2008) considered that the implementation of the activity approach is based on the formation of personal reflection, the reflection of the work and actions. So, we consider activity approach is an important methodological approach to the problem of evaluation of students' educational achievements.

Rubinstein S. L. (1989) and Leontiev A. N. (1976) noted in their scientific works that activity is the basis of the formation of students' personality. The authors state that the primary function of activity is communication, because it is included in the collective communication activities. We see the implementation of this idea in the use of evaluation tools in a virtual educational environment. Schedrovitsky G. P. and Kotelnikov S. I. (1983) consider the implementation of activity approach in using such forms of evaluation as educational and business games. Educational and business games serve as an important form of evaluation of students' educational achievements.

Asmolov A. G. (2009) identifies motivational and technological components of activity. The motivational component of evaluation includes motive and its result. The technological component includes technologies of achieving the aim. Galperin P. Y. (1999) suggests that activity is the gradual formation of mental actions. Thus, the formation of professional competency should be proceeded step by step during the evaluation of students' educational achievements.

The main ideas of activity approach to the organization evaluation of students' educational achievements we see in the following statements:

1. Evaluation of students' educational achievements is realized in dynamic activity. So, it is necessary to choose active forms of evaluation.

2. Professional and personal development of the future specialists is carried out in activity. ation.

3. Reflection is a component of evalu-

4. All types and forms of evaluation of students' educational achievements should be endowed with the personal sense. The personal sense and the attitude of the students to the results of their own activity lead to their personal development.

5. Student is a subject of activity. And, consequently, student is a subject of evaluation. Thus, students should take an active part in the choice of forms and methods of evaluation of their activities.

6. Communication as a part of activity and as part of the evaluation of students' educational achievements is realized both in contact and in virtual educational environments.

7. Subject relations (teacher $\leftrightarrow$ student, teacher $\leftrightarrow$ students, student $\leftrightarrow$ student, student $\leftrightarrow$ students) should be implemented at all levels of evaluation.

Schedrovitsky G. P. and Kotelnikov S.I. (1983) considered that the important aspect of the activity approach was "collective thinking activity". The essence of "collective thinking activity" is the development of the personality which takes place in the joint activity. This position is very important for our study because evaluation of students' educational achievements is seen from the position of such joint activities as teacher $\leftrightarrow$ student, teacher $\leftrightarrow$ 
students, student $\leftrightarrow$ student, student $\leftrightarrow$ students. We see the realization of this position in implementation of the teachers' evaluation of the students' achievements and mutual evaluation of the students. In studies (Leontiev A. N. (1976)) the structure of activity includes motivation, purpose, and condition. El'konin D. B. and Davydov V. V. (1989) saw the implementation of the activity approach in communication and in the formation of personal sense. In their opinion, personal self-improvement and the development of personal potentiality is realized due to the active position of the students.

The next approach which is very important for our research of evaluation of students' educational achievements is contextual approach. This approach is developed by (Verbitsky, A. A., 1990, 1991, 1995, 2004; Agapova, O. I. at all., 1987; Verbitsky, A. A. and Larionova, O. G., 2006; Verbitsky, A. A. and Dubovitskaya, T. D., 2003; Verbitsky, A. A. and Zhukova, N. V., 2006; Verbitsky, A. A. and Kalashnikov, V. G., 2012). When using contextual approach, we should be primarily focused on the professional activities of a future specialist. The purpose of evaluation of students' educational achievements based on the contextual approach is not to obtain the system of information, but the formation of the ability to fulfill future professional activities. Information takes place in the structure of evaluation activities of the student till the certain point. Then this information should be developed into the practical implementation. This means, that educational activity of the students should obtain features of their future professions. According to the contextual approach, the content the evaluation tools should be closely connected with the future professional activity, that gives integrity, system organization and personal meaning to evaluation. Content of evaluation materials is transformed into the object of professional activity. It is important to mention that the contents and conditions of professional activity have always been probabilistic and problematic. Therefore, the basic unit of evaluation of students' educational achievements based on the contextual approach is not a task, which is performed due to the example, but problem situation, which assumes the inclusion of productive thinking of the student. The solution of professional-oriented tasks allows the integration of the competences of future specialists. It also allows natural entry into the profession by means of evaluation of students' educational achievements.
The major task of evaluation based on of the contextual approach is to ensure the transition from training activity to the professional one by means of professional-oriented situations. We consider case study as a successful method of evaluation. The fact is that while organizing the evaluation of students' educational achievements, they fulfill all the requirements of the teachers without showing their own initiative, while the professional activity demands the ability to take the lead, set and achieve goals, which are integral features of the creative development of the personality.

Principles of contextual approach formulated by Verbitsky A. A. (2004) can be successfully implemented in the organization of evaluation of students' educational achievements:

1) The principle of personal inclusion of the students in the evaluation activities. This means organizing of students' self-control.

2) The principle of consistent use of evaluation methods we see in use both traditional methods and innovations (e.g. coaching, flipped learning, BYOD (bring your own device)).

3) The principle of problem-based methods of evaluation involves the use of case study.

4) The principle of the adequacy of forms of evaluation due to its purpose which requires the use of such forms as web-quest and portfolio.

5) The principle of the leading role of the joint activity, interpersonal interaction and dialogic communication that means organization of the mutual control of the students.

6) The principle of combination of traditional and innovative technologies in the organization of evaluation of students' educational achievements.

7) The principle of transparency requires the organization of evaluation of students' educational achievements using the virtual educational environment.

The fact is, that the evaluation of students' educational achievements takes place in an artificial environment, which can not recreate the atmosphere of the professional activities. Besides, the evaluation of educational achievements of students involves the assessment of the personal results, but not the collective ones. The working process usually focuses on joint professional activity. The realization of evaluation of students' educational achievements based on the contextual approach we see in using problem-oriented methods such as case study. It allows to recre- 
ate future professional activity using problemoriented tasks. It is connected to the changes of the social position of the students. That means, that the transition from training activities to the professional activity is a complex process. The implementation of skills is a challenge for many graduates. The system of problem situations allows the formation of theoretical and practical professional thinking of the future specialists.

Evaluation of students' educational achievements based on contextual approach determines the characteristics of its organization. The use of such forms of evaluation as web-quests, seminars, discussions, educational and business games allows to reproduce the future professional work situation.

Evaluation of students' educational achievements suggests using the following forms of evaluation the activity of students:

- Evaluation activities of academic type, which is dominated by the assimilation of information, considering already formed competence as of the students;

- Evaluation activities of a quasi-professional type simulates the conditions of future professional activity, the employment relationships. That means, that the solution of the problems and finding the ways out of the professional situations.

- Evaluation activities of educational and professional type requires performing of the scientific research and practical developments of students (scientific and research work, students' projects, grant applications, participation at the scientific conferences, publication of scientific results at journals, etc.).

However, it should be noted that, contextual education by Verbitsky A. A. (2004), has three models such as semiotic, simulation and social one. The semiotic model is revealed in verbal or written texts, which contain information of a discipline (eg. lecture materials, traditional tasks, instructions for preparation for practical classes, training programs, etc.). Unit of the student work is a substantive action. Evaluation due to the simulation model is a modification of the future professional activity, which requires analysis and decisionmaking based on the theoretical information. Unit of the student work is subject activity, the primary aim of which is the transformation of the practical simulated professional situations. Evaluation based on the social model is a piece of professional activity, which is analyzed and converted into a form of joint activity of the students in the group. Evaluation based on the social model we see in conducting the evalu- ation of educational achievements of the students using the virtual educational environment, where the activity in the interactive groups as the social models of the professional environment leads to the formation of the social competence of the future specialists.

\section{CONCLUSION}

Social and economic processes taking place in the educational environment and the world economy are reflected in the training of qualified specialists for various spheres. Since the labor market requires high demands to the future specialist, there is a need for the formation of specialists of a new type, the main characteristics of whose are high level professional qualification, ability to self-development, critical thinking, solving professional problems of various levels. All the mentioned above facts produce ensuring of the development of education. These factors are prerequisite for the development of some methodological aspects of the evaluation of students' educational achievements at university. Summarizing the results of the theoretical research we conclude, that the evaluation of students' educational achievements at university is characterized by contradictions and problems which require serious consideration. Competitiveness of the future specialists is based on the level of their competencies. Organization of the evaluation of students' educational achievements at university is revealed in various forms and using various methods of evaluation in the contact and virtual educational environment, which should complement each other harmoniously.

Summing up, it should be noted, that the use of the activity and contextual approach to the evaluation of students' educational achievements at university will allow conducting evaluation, the main aim of which is comprehensive development of the students' personality, their creative thinking, personal and professional growth.

\section{Conflict of interests}

Author declares no conflict of interest.

\section{REFERENCES}

Agapova, O.I., Shvets, V. I., Verbitsky, A. A. (1987). Implementing of System and Contextual Approach. Issues of Hight School. Moscow, 47-55. (in Russian).

Asmolov, A.G. (2009). System and Activity Approaches in the Development of a New Gen- 
eration of Standards. Pedagogy, 18-22. (in Russian). Retrieved from https://elibrary.ru/item. asp? id=12785913

Balzer, L. (2006). Wie werden Evaluationsprojekte Erfolgreich? Ergebnisse Einer Delphistudie [How are evaluation projects successful? - Results of a Delphistudy]. Weinheim, 123-135. (in German). Retrieved from http://www.lars-balzer.info/publications/pub-balzer 2006-03.html

Balzer, L. (2013). Bekanntheitsgrad und Nutzung der Evaluations-Standards der Schweizerischen Evaluationsgesellschaft (SEVAL) sowie erste Modifikationshinweise: Ergebnisse der Mitgliederbefragung. LeGes - Gesetzgebung \& Evaluation, 24(2), 439-458. (in German). Retrieved from http://www.lars-balzer.info/publications/ pub-balzer_2013-07_LeGes2013-24(2)_balzer. pdf

Balzer, L. (2015). Evaluation Jugendprojekt LIFT III, 2014. Abschlussbericht. Zollikofen: Eidgenössisches Hochschulinstitut für Berufsbildung EHB IFFP IUFFP, 16. [Evaluation Youth project LIFT III, 2014. Final report. Zollikofen: Swiss Federal Institute of Vocational Education and Training EHB IFFP IUFFP, 16.] (in German). Retrieved from http://www.lars-balzer.info/ publications/pub-balzer_2015-03_LIFTIII2014Abschlussbericht.pdf

Balzer, L., Renold U., Frey, A., Nenniger, P. (2002). Reform der Kaufmännischen Grundausbildung. Band 3: Ergebnisse der Evaluation [Reform of Basic Commercial Training in Switzerland]. Results of Evaluation, Volume 3. Landau, 230. (in German). Retrieved from http://www.larsbalzer.info/projects/projekt rkg.html

Gowin, D. B., \& Millman, J. (1981). Toward Reform of Program Evaluation: Lee J. Cronbach, SR Ambron, SM Dornbusch, RD Hess, RC Hornik, DC Phillips, DF Walker, and SS Weiner. Educational Evaluation and Policy Analysis, 3(6), 85-87. doi:10.3102/01623737003006085, Retrieved from http://journals.sagepub.com/doi/ abs/10.3102/01623737003006085

Davydov, V. V. (1972). Types of Generalization in Training (Logical and Psychological Problems of Constructing Subjects). (in Russian). Retrieved from http://edu-lib.net/drugoe-2/davyidov-v-v-vidyi-obobshheniy-v-obuchenii

Davydov, V. V. (1981). The Category of Activity and Mental Reflection in the Theory of A. N. Leontiev. Soviet Psychology, 19. (in Russian).

Davydov, V. V., Zinchenko, V. P. and Talyzina, N. F. (1982). The Problem of Activity in the Works of A. N. Leontiev. Soviet Psychology, 21. (in Russian). Retrieved from http://www.voppsy.ru/issues/1982/824/824061.htm

El'konin, D. B., Davydov, V. V., Zinchenko, V. P. (1989). Selected Psychological Works. (in Russian). Retrieved from http://fusionpiter.ru/articles/elkonin-chosen-works

Galperin, P. Y. (1999). Introduction to Psychology: Textbook for High Schools. (in Russian). Retrieved from http://pedlib.ru/Books/3/0297/3 0297-1. shtml

Galperin, P. Y., Talyzina, N. F. (1979). The Modern Theory of Stage Formation of Mental Actions. (in Russian).

Galustyan, O. V. (2014). Application of Case Study in E-Learning. Distance and Virtual Education. (in Russian). Retrieved from https://elibrary.ru/ item. asp $? \mathrm{id}=21752697$

Galustyan, O. V. (2015). Digital Campus as Electronic Image of the University. Rupkatha Journal on Interdisciplinary Studies in Humanities, 7(3). Retrieved from http://rupkatha.com/V7/n3/28 digital-campus.pdf

Kromrey, H. (2003). Evaluation in Wissenschaft und Gesellschaft [Evaluation in science and society]. Zeitschrift für Evaluation, 1, 93-116. (in German). Retrieved from http://www.hkromrey. de/Kromrey EvalWissG.pdf

Larionova, O. G. (2005). Competence as a Base of Contextual Learning. Higher Education in Russia. 10, 118-122. (in Russian). Retrieved from https://elibrary.ru/item.asp?id=9574028

Lektorsky, V. A. (2008). Activity Approach: Beginning and Prospects. Bulletin of Tomsk State Pedagogical University. 1, 13-16. (in Russian). Retrieved from https://elibrary.ru/item.asp?id=11621284

Leontiev A. (1976) Signs of Connectivity and Integrity of the Text. Semantic perception of speech communication (within conditions of mass communication) Science. P. 46-47. (in Russian).

Levina, M. M. (2009). Activity Approach as a Methodological Principle of Management of Educational Process of Students. Teacher Education and Science, 2. 4 - 13. (in Russian). Retrieved from https://elibrary.ru/item.asp?id=17062047

Rubinstein, S. L. (1989). Fundamentals of General Psychology. Pedagogy. (in Russian). Retrieved from http://elib.gnpbu.ru/text/rubinshteyn osnovy-obschey-psihologii t1 1989/go,0;fs, 1 /

Schedrovitsky, G. P., Kotelnikov, S. I. (1983). Educational and Business Games as New Form of Organization and Method of Collective Thinking Activity. Innovations in Organizations. 43. (in Russian). Retrieved from http://www.fondgp.ru/ lib/collections/archive/online/83c

Slobodchikov, V.I. (1998). Psychological Problems of Formation of the Inner World of Man. Questions of Psychology. (in Russian). Retrieved from http://www.voppsy.ru/issues/1986/866/866014. htm

Stošić, L. (2015). The importance of educational technology in teaching. International Journal of Cognitive Research in Science, Engineering and Education (IJCRSEE), 3(1), 111-114. Retrieved from http://ijcrsee.com/index.php/ijcrsee/article/view/166

Stosic, L., \& Stosic, I. (2013). Diffusion of innovation in modern school. International Journal Of Cognitive Research In Science, Engineering And Education (IJCRSEE), 1(1), 5-13. Retrieved from http://ijcrsee.com/index.php/ijcrsee/article/ view/7

Verbitsky, A. A. (1990). Person in the Context of Speech: Forms and Methods of Active Learning, 64. (in Russian).

Verbitsky, A. A. (1991). Active Learning at High School: Contextual Approach. (in Russian). Retrieved from http://www.twirpx.com/file/580876/

Verbitsky, A.A. (1995). Independent Work of Students: Challenges and Experience. Higher Education in Russia. 137-145. (in Russian).

Verbitsky, A. A., Dubovitskaya, T. D. (2003). The Contexts of Educational Content. (in Russian). Retrieved from https://elibrary.ru/item. asp? $\mathrm{id}=19878704$

Verbitsky, A. A. (2004). Competence Approach and the Theory of Contextual Learning. (in 
(IJCRSEE) International Journal of Cognitive Research in Science, Engineering and Education Vol. 5, No.1, 2017.

Russian). Retrieved from http://pedlib.ru/ Books/7/0163/7_0163-1.shtml

Verbitsky, A. A., Larionova, O. G. (2006). Humanization and Competence: Context of Integration. (in Russian). Retrieved from https://elibrary.ru/ item.asp? $\mathrm{id}=18696804$

Verbitsky, A. A., Zhukova, N. V. (2006). Problems of Humanization of Education within a New Educational Paradigm. (in Russian). Retrieved from https://elibrary.ru/item.asp?id=19982931

Verbitsky, A. A., \& Kalashnikov, V. G. (2012). Category of «Context» and contextual approach in Psychology. Psychology in Russia: State of the art, 5. (in Russian). doi:10.11621/pir.2012.0007 Retrieved from http://psychologyinrussia.com/ volumes/index.php?article $=1122$

Wottawa, H., Thierau, H. (2001). Evaluation. Pädagogische Psychologie [Evaluation. Educational Psychology]. Bern: Hans Huber. (in German). Retrieved from http://tocs.ulb.tu-darmstadt. de/114351554.pdf

Zaporozhets, A. V. (1986). Selected Psychological Works: Mental Development of a Child. Pedagogy, 2(1), 321. (in Russian). Retrieved from http://www.koob.ru/zaporozhets/psy_works_1

Zaporozhets, A. V. (1986). Selected Psychological Works: Development of the Voluntary Movements. Pedagogy, 2(1), 297. (in Russian). Retrieved from http://www.twirpx.com/ file/1412472/ 